University of Michigan Law School

University of Michigan Law School Scholarship Repository

$5-1977$

\title{
Men Who Know They Are Watched: Some Benefits and Costs of Jailing for Nonpayment of Support
}

David L. Chambers

University of Michigan Law School, dcham@umich.edu

Follow this and additional works at: https://repository.law.umich.edu/articles

Part of the Courts Commons, Family Law Commons, Juvenile Law Commons, and the Law and Society Commons

\section{Recommended Citation}

Chambers, David L. "Men Who Know They Are Watched: Some Benefits and Costs of Jailing for Nonpayment of Support." Mich. L. Rev. 75 (1977): 900-40.

This Essay is brought to you for free and open access by the Faculty Scholarship at University of Michigan Law School Scholarship Repository. It has been accepted for inclusion in Articles by an authorized administrator of University of Michigan Law School Scholarship Repository. For more information, please contact

mlaw.repository@umich.edu. 


\section{MEN WHO KNOW THEY ARE WATCHED: SOME BENEFITS AND COSTS OF JAILING FOR NONPAYIIENT OF SUPPORT}

\section{David L. Chambers* $\dagger$}

Suppose that by some mysterious process the police in your town received each Monday a list of all the robberies and burglaries committed during the preceding week and the names of the persons who committed them. Suppose further that the list itself was admissible in evidence at trial and generally led to conviction. And suppose finally that persons considering committing offenses knew that the police had such a list and used it, relentlessly tracking down the miscreants named on it. Under such circumstances, one would probably expect that many potential offenders in the town with the magical list would resist the temptation to rob or burgle stores.

For one offense, such a list does exist. For over fifty years, each county government in Michigan has maintained an agency called the Friend of the Court that is responsible for receiving all child-support payments from parents under orders of support after a divorce or adjudication of paternity. The agency knows on Monday if the parent under an order of support failed to make a payment the preceding Friday, and the parent under an order of support, almost always the father, knows that the agency knows. He is also aware

\footnotetext{
* Professor of Law, The University of Michigan. A.B. 1962, Princeton University; LL.B. 1965, Harvard University.-Ed.

$t$ (C) David L. Chambers 1977. This article reports part of the findings of a study of child support conducted over a five-year period. The full results should be available in 1978. A grant from the National Science Foundation provided funds for several stages of the study, including the stage reported here. Additional funds were provided by the Center for Studies in Criminal Justice at The University of Chicago and the William W. Cook Research Funds of The University of Michigan Law School.

The study would have been impossible without the active cooperation of the Friends of the Court in the 28 counties we examined. To them, and especially to Robert Standal of Genesee County and Richard Benedek of Washtenaw County, I am immensely grateful. I am also grateful to the score of persons who have worked on the project at various times. Three require special mention here: Ray $M$. Shortridge, who served as my research associate from 1974 to 1976, and who shaped and oversaw the execution of much of the 28 county phase of the study; Terry $K$. Adams, who served as research associate in earlier phases and has advised me throughout; and Priscilla Cheever, who has performed nearly all of the computer work for the last several phases of the project. William Birdsall, economist on the faculty of The University of Michigan School of Social Work, assisted me greatly by his comments on the drafts of this article.
}

[900] 
that, if he does not make the payment, he stands a risk of being arrested by the agency's own deputized officers and sentenced to jail by a judge for civil contempt for failing to obey the court order. Each year Michigan judges sentence thousands of men for nonsupport-in 1974 around 4000, and probably more today. On any given day in several Michigan counties, the number of men in the local jail under sentence for nonsupport commonly exceeds the number under sentence for all other jailable offenses combined.

How do fathers behave in places with such a list and an ardent enforcement staff? If all fathers who can pay do so without prodding because of their affection for their children, even an omniscient and industrious police force would have no effect on payments. Nor would the police have an effect if those men who do not pay are men so angry or bitter that even fear of jailing would serve as an inadequate prod. ${ }^{1}$ Unless love or anger is so powerful, however, one would expect that knowledge that an agency is aware of their nonpayment would cause some fathers to pay who otherwise would not, and the additional knowledge that the agency acts forcefully against nonpayment would lead even more to pay. The system should have effects.

For five years, a number of associates and I have been recording and analyzing data from the files of Michigan's Friends of the Court. We find, sad to say, that love alone fails to propel most parents into regular payment. On the other hand, we find that a well-oiled enforcement process capped by a substantial reliance on jail seems to lead significant numbers of men to pay who otherwise would not, although we cannot say with certainty whether the link between payments and jail is through fear of being jailed or some more subtle process of conveying through the use of jail the seriousness of a social obligation.

How we reached our conclusions about jail's effects on payments is the subject of this essay. For readers unfamiliar with research on deterrence, I hope the study can serve, as it has for the author, as a palatable introduction to a form of inquiry often reported in unnecessarily obscure terms. For those familar with such research, the study may still have value, for the nature of the offense and the

1. The angriest account of the divorce process from a male perspective that $I$ have read is M. FrANKs, How To Avord AlimoNY (1975), an altogether nasty book. A fine, tempered book is J. EPSTEIN, DivorCED IN AMERICA (1974). An early study of women after divorce that remains impressive and timely despite its age is $W$. GOODE, WOMEN IN DrVORCE (1965), originally published as W. GOODE, AFTER Drvorce (1956). 
thoroughness of the public records have permitted us to measure the effects of a jailing policy with considerably greater precision than is usually possible. For both groups, the study may reveal a processthe enforcement of child support-about which most people know very little.

Many states are moving swiftly to improve their systems for collecting child support in welfare cases. They are doing so to conform to recent federal legislation that conditions full reimbursement of welfare costs to the states on their making much more organized efforts than in the past to secure and enforce support orders against absent fathers. ${ }^{2}$ Our findings, if read too hastily, might lead some people to conclude that payment levels can be improved simply by jailing a large number of nonpayers. Our findings do not support this conclusion; rather, they suggest that jailing makes a significant difference in collections if, but only if, it is coupled with a wellorganized and visible system of other efforts to collect. There are no easy shortcuts.

More than money is at stake when we jail people. After reporting our findings on the deterrent effects of jailing, we will share some of our doubts about the wisdom of relying heavily on jail even if it does yield more dollars than it costs. We will then examine briefly an alternative to the use of jail that may be more effective even when measured solely by the return in dollars collected.

\section{The Nature of the Research}

Research on deterrence often focuses on persons on whom a particular sanction has been imposed to learn whether they commit the same acts again. Parts of our research included such an inquiry, but in this article we do not report on these men. Here we will deal with the effects of the use and threat of jail on the whole population who may commit an offense, the so-called "general deterrent" or "general preventive" effects. We will look, that is, at how the punishment of some fathers affects the behavior of all fathers, including those who are never arrested or jailed. Measuring these effects is a vexing task. ${ }^{3}$ When large numbers of men who have been

2. See Title IV(D) of the Social Security Act, 42 U.S.C. $\$ \S 651-660$ (Supp. V 1975). Throughout this article, the term "welfare" refers to the program of Aid to Families with Dependent Children established by Title IV of the Social Security Act.

3. Among lawyers and social scientists, three persons have been largely responsible for providing a theoretical foundation for deterrent research and for cataloguing its pitfalls. The first is Johannes Andenaes of the University of Oslo. See, e.g., Andenaes, General Prevention-Illusion or Reality, 43 J. CRIM. L.C. \& P.S. 176 
jailed make lump-sum payments immediately preceding their release and immediately after release begin a period of regular payments for the first time in years, we can be fairly confident in most cases of a causal link between the jailing and the payments. When we look, however, at the records of men never jailed and find steady payments year after year, we cannot say anything about whether fear of jail, rather than affection for the child or something else, produced their payments.

To look for such "general deterrent" effects of jailing on the behavior of a group who might commit an offense, social scientists typically use either of two risky methods of inquiry. ${ }^{4}$ Under one method, a single place-a state, a county-is followed through time to examine the relationship between changes in the incidence of the undesired behavior and changes in the rates of imposing certain sanctions. As the jail rate or hanging rate increases, does the crime rate decline? This was the method employed by Isaac Ehrlich in his recent and much-discussed study of the general deterrent effects of the death penalty. ${ }^{5}$ Under the other model, several placesseveral states or counties-are examined, typically during a common period of time, in an effort to see whether the places that jail or execute more offenders have a lower incidence of the undesired behavior. Thorsten Sellin employed this method in an earlier and no less celebrated study of the death penalty. ${ }^{6}$ It is also the method used in the study reported here.

That the two death penalty studies reached opposite conclusions on the same issue suggests the difficulties deterrence research en-

(1952); Andenaes, General Deterrence Revisited: Research and Policy Implications, 66 J. CrIM. L. \& C. 338 (1975). The other two are Franklin Zimring and Gordon Hawkins, authors of F. ZimRING \& G. Hawkins, DetrrRence-The Legal Threat IN CRIME ConTror (1973). Economists have also become interested in deterrence research. See, e.g., Becker, Crime and Punishment: An Economic Approach, $76 \mathrm{~J}$. POL. ECON. 169 (1968); AMERICAN ENTERPRISE INSTITUTE FOR PUBLIC Policy Research, Economics of Crime aNd Punishment (Rothenberg ed. 1973).

4. See F. Zimring \& G. Hawkins, supra note 3, at 249-93.

5. Ehrlich, The Deterrent Effect of Capital Punishment: A Question of Life and Death, 65 AM. EcoN. Rev. 397 (1975). A series of responses and comments to Ehrlich have been published recently in the Yale Law Journal. See Baldus \& Cole, A Comparison of the Work of Thorsten Sellin and Isaac Ehrlich on the Deterrent Effect of Capital Punishment, 85 YALE L.J. 170 (1975); Bowers \& Pierce, The Illusion of Deterrence in Isaac Ehrlich's Research on Capital Punishment, 85 YALE L.J. 187 (1975); Ehrlich, Deterrence: Evidence and Inference, 85 YALE L.J. 209 (1975); Ehrlich, Rejoinder, 85 YALE L.J. 368 (1976); Peck, The Deterrent Effect of Capital Punishment: Ehrlich and His Critics, 85 YALE L.J. 359 (1976). See also Zeisel, The Deterrent Effects of the Death Penalty: Facts v. Faiths, 1976 SuP. CT. REv. 317.

6. T. Sellin, The Death Penalty (1959). 
counters. All such research depends upon accurate counts of comparable data. It must begin with reasonably precise figures, either across locations or through time, of the incidence of the undesired behavior and of the sanction the impact of which one is seeking to gauge. Usually the frequency of imposing a certain sanction can be counted by poring through court records, but for many offenses, such as drug sales or larceny, it is much more difficult to determine the actual incidence of the undesired behavior. Figures on citizen complaints or police arrests may reflect quite unevenly across time or locations the actual incidence of the behavior.

After obtaining accurate information about the crime and the punishment, one can see whether there is less of the undesired behavior in places that make substantial use of penal sanctions. Half the job remains, however, for one must then determine whether the relation between sanction and conduct is actually a mirage: ${ }^{7}$ whether, that is, some aspect of the enforcement process other than the incidence of sentences to jail-for example, the swiftness in sending reminders that payments are due-more adequately or wholly explains the relation between punishment and crime. Or, apart from any aspects of the enforcement process, perhaps what appear to be the effects of enforcement are properly attributable to differences in the characteristics of the population or to changes in the same population over time, differences that might affect attitudes toward the conduct or responsiveness to the same enforcement efforts. It is this latter part of the undertaking that has most bedeviled researchers into deterrence and has most bedeviled us.

\section{The Twenty-Eight County Study}

\section{A. Michigan's Friends of the Court and the Enforcement of Support}

Among American jurisdictions, Michigan's Friend-of-the-Court system is quite unusual. In most states, if a parent under an order of support fails to make payments, the custodial parent discovers that, unless she is a recipient of welfare benefits, there is no agency comparable to the Friend of the Court to which she can turn for assistance in enforcing the order. She must hire her own attorney to search for the father and bring him to court by civil processes. In Michigan, by contrast, a Friend of the Court in each county oversees all aspects of the child-support process in divorce, separate

7. The opposite phenomenon can also occur: a relationship between crime and punishment does not appear initially but emerges after controlling for other variables, 
maintenance, and paternity cases. ${ }^{8}$ The agency begins each case by gathering financial information from the parents and advising the judge on the appropriate size of the support order. After an order is entered, it collects all payments and forwards them to the appropriate receiver, either the custodial parent or the welfare department. Finally, it pursues the parents who fail to pay. In nearly all cases in which a support order is entered, payments are handled through the agency. Its responsibilities extend equally to welfare and nonwelfare cases.

To carry out these tasks, a few small counties have only one or two full-time employees. By contrast, the Friend of the Court in Wayne County, the core of the Detroit metropolitan area, has a staff of over three hundred. Most agencies of any size have computerized payment records and full-time enforcing officers, many of them deputized by the county sheriff, who go into the field to arrest men who have not paid.

Jailing plays a part in this process because the willful or negligent failure to make payments ordered by the court is treated as a form of contempt that, by special state statute, can lead to a sentence in jail of up to one year, subject to earlier release upon the defendant's paying his full arrearage or working out some lesser arrangement satisfactory to the court. ${ }^{9}$ Most men jailed do in fact purchase their early release by paying an amount less than full arrearage.

The steps taken before jailing and the extent of reliance on jail vary from county to county, but in every county the agency mails warning letters to delinquent fathers, and nearly all agencies issue orders to show cause directing the men to appear in court to explain their delinquency. Even in the counties that rely most upon jailing, the number of collection efforts short of jail dwarfs the number of sentences; in one that we examined particularly closely, for example, warnings mailed to men in the caseload exceeded jail sentences imposed by twenty-five fold. For men who fail to appear in response to warnings and orders to show cause, the agency staff secures and, in many counties, serves arrest warrants and then acts as prosecutor before the courts in delinquency hearings. After a hearing, if the man is sentenced, the same staff arranges deals with jailed men who wish to secure their early release from jail on payment of less than the full arrearage.

8. Michigan's legislature authorized the creation of Friends of the Court in 1919, 1919 Mich. Pub. Acts 412, and then made them mandatory in 1921, 1921 Mich. Pub. Acts 147. The provisions of current law that provide for Friends of the Court and fix their duties are found in Mich. CoMp. LAws $\$ 552.251-.255$ (1970).

9. See MICH. CoMP. Laws § 552.201 (1970). 
Our study of jailing for nonsupport was undertaken because we found that rather like the biologist's fruitfly or guinea pig, nonsupport lends itself to closer inquiry than is possible with most other forms of behavior treated as criminal. As watchdogs over custody and support, the agencies maintain records of every aspect of the process: their files include information on family characteristics, weekly payments, and enforcement efforts. Their records and their cooperation made our inquiry possible.

\section{B. The Research Design and Findings}

As our first step, we drew a random sample of divorce cases in each of twenty-eight Michigan counties. The counties we picked were those in the southern half of Michigan that had reported caseloads of at least 1,000 in $1973 . .^{10}$ Stretching from the eastern to western edges of the state, the counties contained all the cities in the state with 1970 populations of more than 50,000 and included all but one of the counties with populations of more than 100,000 . On the other hand, four of the counties had populations under 50,000 and ten had populations under 80,000 . Our research thus examined data sources ranging from the intensely urban southeastern corner through counties of farms and small towns.

The samples we drew in each county averaged 430 cases, for a total across the twenty-eight counties of about 12,000 cases. In each county, we drew a random ${ }^{11}$ selection of all cases in which a final decree of divorce had been entered and an order of support had been in effect during the entire period we measured. Thus men paying every week were included, as well as men whose cases had been open for many years but who had never paid anything. For each case in each county, we recorded only a few pieces of information: the amount each person paid, the total amount he was under an order to pay during a fixed period, and whether the children covered by the support order were currently receiving welfare benefits. In most

10. The counties studied were Allegan, Barry, Bay, Berrien, Branch, Calhoun, Cass, Eaton, Genesee, Gratiot, Ingham, Jackson, Kalamazoo, Kent, Lapeer, Lenawee, Livingston, Macomb, Midland, Monroe, Oakland, Saginaw, St. Clair, St. Joseph, Shiawassee, Van Buren, Washtenaw, and Wayne. Two other counties, Muskegon and Ottawa, had caseloads meeting the numerical criterion we set. However, scheduling difficulties prevented our studying their files.

11. In all but a few counties, payment records were maintained in alphabetical order. To produce our random samples for these counties, we simply determined the size of the caseload and selected an interval (e.g., every seventh case or every twelfth case) that would permit us to cull about 450 cases by moving once through the alphabet. 
counties the period we used was calendar 1974 or a one-year period including some months in 1974, depending on the way the counties' bookkeeping records were kept. From this information, we computed how much each man had paid of all that he was supposed to have paid during the period-his batting average, so to speak. ${ }^{12}$

We then computed three payment figures for each county: the overall average of the individual payment rates within the county, a figure that is close, though not identical, to the portion collected by the county of all the dollars it was supposed to collect; ${ }^{13}$ the portion of men in the county paying nearly nothing during the period (we put into this group men paying $10 \%$ or less of the ordered amount); and the portion of men paying everything due or close to everything due (we put into this group men paying $80 \%$ or more of everything due).

Checking the records of a county for any given one-year period, one would probably expect to find that most men either paid nothing or paid regularly, leaving few men in the middle. And in fact that is what we did find. The striking differences among our counties were in the portions of payers at the bottom and the top. Across the counties, the proportion of men in the high-paying bracket varied from one-third to two-thirds of the caseload; the proportion in the low-paying bracket ranged from one-tenth to one-half. Accordingly, across the counties the average portion paid by men of their amounts due varied widely-from a low in two counties of only $45 \%$ and

12. In most counties, we used the following formula: $\frac{d}{t w}$, where $d=$ dollars paid during period, $t=$ number of weeks in period, and $w=$ weekly order in dollars. In some counties, where the records provided only a running total of the arrearage and no total of the dollars paid during a period, we used a different formula: $t w-\left(a_{2}-a_{1}\right)$

of period, and $t$ and $w$ represent the same values as above. So long as there were no artificial adjustments in the arrearage during the period, the two formulae yield identical results. Because there were in fact some such alterations in the arrearage not reflecting actual payments, usually to the payer's advantage (for example, when a credit was given because the noncustodial parent kept the children for an extended visit), we made a small adjustment downward in the payment figures for the counties in which we had to use the second formula. The adjustment was based on our experience in two counties, Washtenaw and Genesee, in which we had computed individual payment records by both formulae.

13. The figures would be identical if all orders were of the same size. Within our samples in Genesee and Washtenaw, there were, of course, variations in the size of orders, and there was in fact a very slight positive correlation between order size and payment rate, so that it is probable that the figure we use, the mean of individual payment rates, is quite close to (but slightly lower than) the portion the agency collected of everything due under all its orders. 
$46 \%$ of the ordered amounts to a high in two other counties of $85 \%$ and $87 \%$ of everything due. Nearly half the counties collected between $61 \%$ and $70 \%$ of the amounts due. Table 1 reveals the distribution of collections in the counties. We found that the portion at the bottom and the top correlated so overwhelmingly with the mean level of payments that we have used the county's mean for reporting almost all of our findings. ${ }^{14}$

\title{
TABLE 1
}

\author{
Mean Portions Collected of Everything Due from \\ Divorced Persons Under ORders of Support \\ In Twenty-Eight Michigan Counties \\ During Survey Period, 1974-1975
}

\begin{tabular}{|c|c|c|c|c|}
\hline $\begin{array}{l}\text { Counties Collecting } \\
\text { a Mean of }\end{array}$ & $\begin{array}{c}\text { No. of } \\
\text { Counties }\end{array}$ & $\begin{array}{c}\% \text { of } \\
\text { Counties in } \\
\text { this Range }\end{array}$ & $\begin{array}{c}\% \text { of } \\
\text { Fathers } \\
\text { Paying 10\% } \\
\text { or Less }\end{array}$ & $\begin{array}{c}\% \text { of } \\
\text { Fathers } \\
\text { Paying } 80 \% \\
\text { or More }\end{array}$ \\
\hline $\begin{array}{l}41-50 \% \text { of amount due } \\
51-60 \% \text { of amount due } \\
61-70 \% \text { of amount due } \\
71-80 \% \text { of amount due } \\
81-90 \% \text { of amount due }\end{array}$ & $\begin{array}{r}2 \\
5 \\
13 \\
6 \\
2\end{array}$ & $\begin{array}{r}7 \% \\
18 \% \\
47 \% \\
21 \% \\
7 \%\end{array}$ & $\begin{array}{r}47 \% \\
38 \% \\
24 \% \\
16 \% \\
8 \%\end{array}$ & $\begin{array}{l}32 \% \\
42 \% \\
50 \% \\
60 \% \\
72 \%\end{array}$ \\
\hline & 28 & $100 \%$ & $25 \%(\mathrm{~m}$ & an) $\overline{51 \%}$ (mean) \\
\hline
\end{tabular}

When we speak, as we will shortly, of some counties as highcollecting, we need to remember that, even in the two counties with the highest mean payments, nearly $30 \%$ of the men paid less than $80 \%$ of the total amount due. ${ }^{15}$ Thus, even in the high-collecting counties, many women and children already in precarious financial condition $^{10}$ went without needed income. Throughout, when we speak of high collections, we intend solely to convey relative levels of payment.

After determining the levels of collections for each county, our goal was to determine why some counties collected so much more

14. The product-moment correlation between the overall mean and the portion of the caseload paying less than $10 \%$ of everything due was -.935 . The productmoment correlation between the mean and the portion of the caseload paying more than $80 \%$ was +.899 .

15. In 1974, unemployment was at disastrously high levels throughout Michigan. Our findings suggest that nearly all the counties would have somewhat higher collection rates during periods of lower unemployment. See note 25 infra.

16. See generally W. Goode, supra note 1; H. Ross \& I. Sawhill, Women IN Transition (1975). 
than others, despite the fact that all counties had Friends of the Court charged with enforcing orders. We were primarily interested in measuring the impact of the use of jailing as a technique of enforcement. To this end, we counted for each county the number of persons sentenced to jail during calendar year 1974. A few Friends of the Court maintained their own logs of all persons sentenced; more frequently we were forced to turn to the logs of the judges of each Circuit Court and scour the year's records of all court business for postings of sentences for nonsupport.

We found, as we had expected, a range of reliance on jail in 1974 from almost no jailings in a few counties up through several hundred jailings in a few others. Table 2 reveals the frequency of sentences to jail in absolute numbers and in terms of the rate of jailing for every 10,000 persons in the county (a figure that closely parallels the number of jailings as a portion of the Friend of the Court caseload). ${ }^{17}$ Nearly all the Friends of the Court reported that the numbers jailed in 1974 had been much the same in the immediately preceding year or two.

\section{TABLE 2}

\section{InCidence IN TWenty-Eight Michigan Counties of SENTENCES TO JAIL FOR CONTEMPT OF COURT FOR FAILURE TO PAY SUPPORT IN 1974}

\begin{tabular}{l} 
Number of Men Sentenced to Jail \\
for Nonpayment in 1974 \\
\hline Under 10 men \\
$11-30$ men \\
$31-100$ men \\
$100-300$ men \\
Over 300 men
\end{tabular}

Number of Sentences to Jail for Nonsupport in 1974 Per 10,000

Persons in County* (1970 census)

$0-1$ per 10,000

$2-3$ per 10,000

4-6 per 10,000

7-10 per 10,000

11 or more per 10,000

\begin{tabular}{cc}
$\begin{array}{cc}\text { Number of } \\
\text { Counties }\end{array}$ & $\begin{array}{c}\text { Per cent of } \\
\text { Counties }\end{array}$ \\
6 & $21 \%$ \\
9 & $32 \%$ \\
7 & $25 \%$ \\
3 & $11 \%$ \\
$\frac{3}{28}$ & $11 \%$ \\
\hline
\end{tabular}

\begin{tabular}{rr}
8 & $29 \%$ \\
8 & $29 \%$ \\
6 & $21 \%$ \\
3 & $11 \%$ \\
3 & $11 \%$ \\
\hline 28 & $101 \%$
\end{tabular}

Total Sentences to Jail in 28 Counties (1974) - 3046 men (of a total caseload of around 290,000 )

* Roughly equivalent to the number of jailings for every 250 persons in the Friend-of-the-Court caseload in 1974. See note 14 supra.

17. The size of the caseloads of the Friends of the Court and the populations of the counties correlate very highly, largely because the divorce rate varies remarkably little among the Michigan counties in our sample. In fact, the correlation is 
We found a substantial positive correlation $(+0.492)$ between the counties' rates of jailings and their rates of collections: in general, the more they jailed, the more they collected. ${ }^{18}$ But this finding, though striking, was the merest beginning. Our task then was to develop measures of all the other factors that might also affect performance and then learn whether the apparent relationship between jailing and collections still held.

As a starting point, it was possible that jailing had a relation to collections through a more subtle link than the bare jail rate alone. For example, men might have been affected not by the mere incidence of jailing but rather by the sentencing rate among those summoned to appear at a hearing for nonpayment, or they might have been affected by some combination of the sentencing rate and the length of sentences commonly imposed. We accordingly developed indices to test for these possible causal links.

It was also possible that the jailing rate had nothing directly to do with payment rates at all. Counties that jailed more might well have had enforcement agencies that tried harder in other respectssent more warnings, held more hearings, used larger enforcement staffs-and one or more of these other factors and not the jailing rate might actually best explain variations in performance. Accordingly, we gathered as much information as we could about all aspects of the counties' collections and enforcement systems-staff-caseload ratios, the use of computerized records, the rate of use of orders to show cause, and so forth.

so high that we were unable to test whether awareness of the possibility of jail, and thus the deterrent effect, depends on the size of the caseload or on the population. Within the counties in our study, the ratio of the county's population (in 1970) to number of men (or families) making up the caseload (in 1974) ranged from about $35: 1$ to $40: 1$. Thus our figure of the "number of jailings per 10,000 population" is roughly equivalent to the "number of jailings per 250 men in the caseload." We have consistently used the population figure as the denominator because in a few counties we were never confident that we had a precise count of the caseload of orders still in effect.

18. Here is another view of the relationship between collections and the rate of jailing:

\section{RELATION OF JAILING TO COLLECTIONS IN} TWENTY-EIGHT Michigan COUNTIES

\begin{tabular}{lcc}
$\begin{array}{l}\text { Number of Jailings } \\
\text { per } 10,000 \text { persons } \\
\text { in County: }\end{array}$ & $\begin{array}{l}\text { Number of } \\
\text { Counties: }\end{array}$ & $\begin{array}{l}\text { Mollections: (mean } \\
\text { of average portion } \\
\text { collected of } \\
\text { amounts due) }\end{array}$ \\
\hline $0-1$ per 10,000 & 8 & .60 \\
$2-3$ per 10,000 & 8 & .63 \\
$4-6$ per 10,000 & 6 & .67 \\
7 or more per 10,000 & $\frac{6}{28}$ & $\frac{.75}{.655}$ (mean)
\end{tabular}


Additional factors had to be taken into account. Payment performance could be affected by factors that varied from county to county but had no direct connection with the enforcement system. More fathers might have paid in County A than in County B-and a higher proportion of nonpayers jailed-because the people in County A felt more strongly about obligations of support or about their general obligations to obey the law or to adhere to social convention. Lacking county-by-county polls of citizen attitudes, we coded a wide range of possible, but quite indirect, indicators of attitude, such as the portion of county population living in a rural setting, total population and population density, conservative voting patterns, general crime rates, and formal church membership. We also recorded the results of our own survey of the attitudes of each county's Friend of the Court toward the functions of the enforcement process and toward possible legislative changes in the enforcement system.

We lastly coded information about income and unemployment rates because it was plausible, indeed likely, that men in all counties were not equally able to pay. For this we drew on 1970 census information about median incomes and portions of the population above and below various income levels and on census and Michigan Employment Security Commission figures regarding levels of unemployment.

It was during the phase of the study that we sought to control for the multitude of factors apart from jailing that might have affected payments that we skated on thinnest ice. We ourselves had computed parents' payment rates and developed confidence in our accuracy. We had similarly counted with care the exact number of men sentenced to jail during a common time period. But for the remaining factors other than the incidence of jailing that might have affected payment rates, we encountered the problems that have plagued all social scientists performing research on deterrence. ${ }^{19}$

Certain problems stood out above the others. First, for many plausible factors that might have affected payments-especially, as we have said, those bearing on people's attitudes toward their obligations-we often had to resort to the most oblique sorts of evidence. Even unemployment data was available only for residents of each county as a whole and so may not have accurately reflected actual rates of unemployment among men under orders of support.

19. See F. ZimRIng \& G. Hawkins, supra note 3, at 264-66, 269; Baldus \& Cole, supra note 5 , at $177-83$. 
Secondly, when there was information that we could code, we had to worry about the comparability of the information across counties. For example, the seemingly simple task of counting the size of county "enforcement staffs" forced us to grapple with many different definitions given the term "enforcement" by the agency heads we interviewed and with multiple uses of individual staff members.

Finally, some sorts of information that were available and reliable displayed so little variation among the counties that we were unable to assess the significance of certain elements of the enforcement process or of the demography of the population of supporting fathers. For example, in setting orders, the counties made use of quite similar schedules that took into account men's earnings and the number of dependent children. (In nearly all, for example, the size of the support order for a family with two children was about onethird of the father's take-home earnings.) Because of the similarity across counties, we were unable to test for differences in collections that might have accrued from larger or smaller orders in relation to incomes.

After gathering all the relevant information that we could, we used multiple regression analysis to determine which factors best accounted for the differences in collections among the counties. Regression analysis is a technique used by social scientists and others to estimate the relationship between factors through the use of numerical data. ${ }^{20}$ Complex in formula, yet readily accessible through computer programs, it permits one to estimate the relation between some phenomenon one wishes to understand (here, the level of payments across counties) and other measured factors that might have a bearing on that phenomenon (jailings, median incomes, and so forth). It permits learning the direction and strength of the relationships among the factors used in the analysis.

When we completed a long series of analyses of our own data, three factors stood out among all others as powerfully related to the levels of collections of support. The first was an aspect of the enforcement process: fourteen aggressive Friends of the Court, which we will call "self-starting," watched for a few weeks of missed payments or the accumulation of an arrearage of a certain number of dollars (say \$100) and then sent a warning notice to the nonpaying parent. These counties that had a practice in nonwelfare cases of initiating enforcement efforts without waiting for complaints from

20. An explanation of regression analysis readily accessible to most lawyers is Finkelstein, Regression Models in Administrative Proceedings, 86 HARv. L. Rev. 1442 (1973). A helpful basic text is H. BLALOCK, Soctal Statistics (1960). 
the mothers collected more than those that relied on complaints. ${ }^{21}$ The second significant factor was the rate of jailing. Even after controlling for other factors, counties that jailed more men in relation to their population still collected more. The third factor was population-the larger the county, the lower the collections. For example, none of the seven highest collecting counties had populations greater than 70,000. Nine of the ten lowest collecting counties had populations greater than $100,000 .^{22}$ Table 3 summarizes our findings with regard to these three factors, doing so at the cost of simplifying for display the true variations in population and rates of jailing.

These three factors were interrelated to some degree. The selfstarting enforcement policy brings more men into the enforcement system, which in turn brings more men before judges for possible sentencing; similarly, large counties were somewhat less likely to be selfstarters. Nonetheless, each of the three factors had independent explanatory importance. The three principal factors alone account for about $60 \%$ of the variation in payment rates among the counties. $^{23}$ Put another way, if you knew any Michigan county's population, whether its agency was self-starting, and its frequency of jailing, you could within our sample predict, typically within a few percentage points, how much the county actually collected of the total amount owed. ${ }^{24}$

21. In the regression analysis we used a simple binary variable that captured whether or not the agency had an established practice in nonwelfare cases of initiating enforcement efforts without awaiting complaints.

22. Not surprisingly, the relation between population and collections is not what social scientists would call "linear." A rise in county population from 30,000 to 130,000 will have far more impact on collections than a rise from $1,030,000$ to $1,130,000$. In our analysis, we used the $\log _{10}$ of population as a more plausible indicator of the relation of population to performance.

23. A list of all variables analyzed may be obtained by writing the author directly. In a regression analysis with the three factors only, the three explained $62.4 \%$ of the variance (unadjusted) and $57.7 \%$ of the variance (adjusted). See Appendix at the end of the article.

When we created a binary variable that contrasted all counties that were selfstarting and high-jailing (four or more jailings per 10,000 population) with all other counties not having both enforcement policies, we accounted for $71.9 \%$ of the variance (unadjusted) and $69.7 \%$ (adjusted) with this variable and the population variable alone. See Appendix at the end of the article.

24. When we calculated what a county should be expected to collect within our sample using the regression coefficients for population, the jail rate and the "selfstarting" factor, the actual collections varied from the predicted collections by more than six percentage points for only nine counties. For eleven counties, the prediction was off by less than three percentage points. Only one county, our highest collecting county, collected over ten percentage points more than would be predicted. That county impressed us even before surveying its records as the most thoroughly organized of all. Conversely, only one county, one of our two lowest collecting, collected more than ten percentage points less than was predicted. This county seemed abour the least well organized for collections. It was the only county in our sample with a 


\section{TABLE 3}

\section{INTERRELATION OF THREE MOST IMPORTANT \\ FACTORS RELATING TO COLLECTIONS IN TWENTY-EIGHT MICHIGAN COUNTIES}

How much the county jails, whether Friend of the Court initiates enforcement without awaiting complaints, and county population

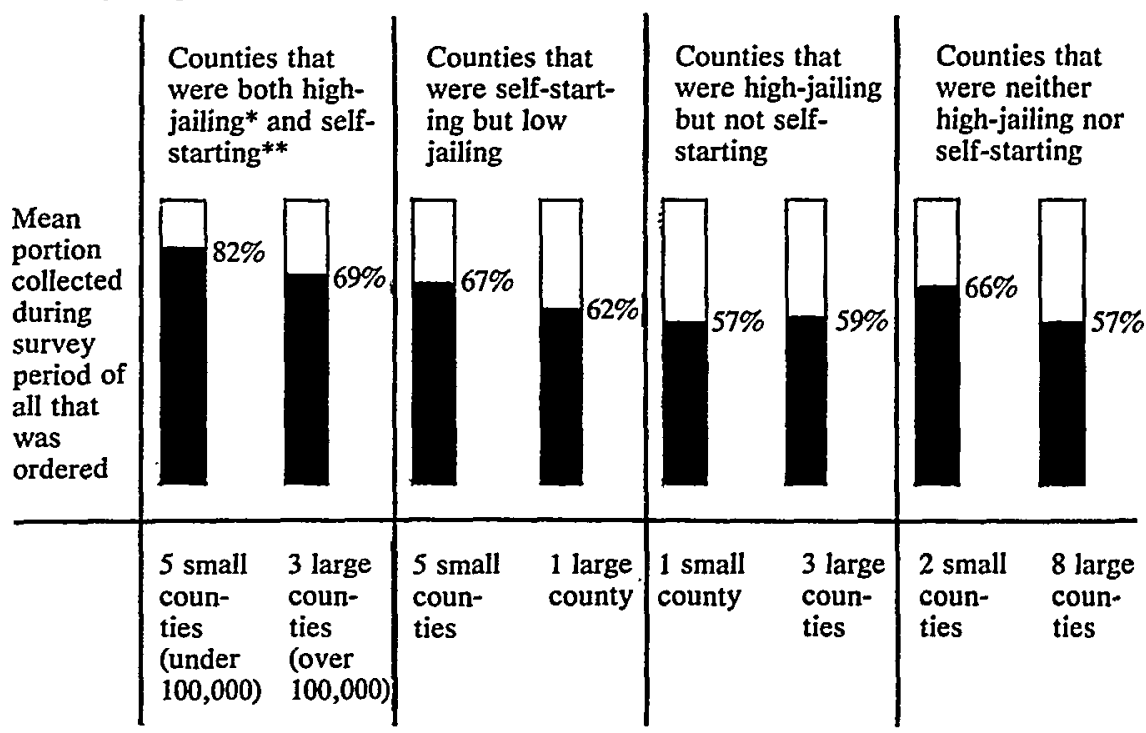

Mean collections:

13 small counties (under 100,000$)-72 \%$

15 large counties (over 100,000$)-60 \%$

12 high-jailing counties*-71\%

16 low-jailing counties- $61 \%$

14 self-starting counties**_-71\%

14 non-self-starting counties-60\%

5 small, high-jailing, self-starting counties- $-82 \%$

8 large, low-jailing, non-self-starting counties-57\%

* A high-jailing county, for our purposes, was one that jailed 4 or more men for nonsupport during 1974 for each 10,000 persons in the county population in 1970. The mean jailing rate for the high-jailing counties was $6.0 \mathrm{per} 10,000$. The mean rate for the low-jailing counties was 1.7 per 10,000. See further explanation in Appendix A.

* A self-starting county was a county that had had for some years a policy of initiating enforcement efforts in delinquent nonwelfare cases without waiting for complaints.

One other factor helps slightly in explaining differences in collections. When unemployment rates are higher, collections are lower. It is not, of course, surprising that payments should be lower in places where unemployment is high. It was surprising to us only

population over 100,000 whose agency head had only a part-time appointment. Later in this article, we discuss Washtenaw County, a low-jailing, non-self-starting county. The ill-organized county to which we are referring in this footnote is not Washtenaw. 
that unemployment rates did not account for more of the differences among the counties. By adding in the unemployment factor, we could account for differences among the counties only to a slightly greater degree than we could using the three dominant factors alone. ${ }^{25}$ An appendix at the end of this article provides for the reader who is interested more detailed statistical information on the findings.

The rate of jailing makes a difference in collections, but how much of a difference? Table 3 and our own analysis indicate that, for purposes of measuring the difference, it makes little sense to separate the jail rate from the factor of a self-starting enforcement process. The two work together. ${ }^{26}$ Counties that have both a high jail rate and a self-starting system collect more than those that have neither and more than those that have one or the other but not both. And those that have one or the other but not both collect only very slightly more than those that have neither. When they are linked together and population and unemployment are taken into account, counties with both a high jailing rate and a self-starting policy collected an average of $25 \%$ more per case than was collected by the counties that did not have both. ${ }^{27}$

\section{The Significance of a Self-Starting Enforcement Process, the Rate of Jailing, and Population}

We have dismembered a complex and emotional process-the payments of divorced parents toward the support of their children.

25. The mean and median unemployment rate in our 28 counties was $10 \%$. In nine of our counties the rate was $12.0 \%$ or more. In only eight was the rate less than $8.0 \%$. Oddly, these rates were not useful in accounting for any of the difference, whereas the 1970 rates, when unemployment rates were lower but still checkered, were able to explain some of the variance in county collections.

With the four variables we could explain $65.6 \%$ of the variance (unadjusted) and $59.7 \%$ (adjusted). The addition of unemployment figures does produce a realignment of the ranking of important factors: population and the jail rate are now somewhat more significant than "self-starting" enforcement. See details in the Appendix at the end of the article.

26. As explained in note 23 supra, a single variable that combines the "selfstarting" factor with the jail rate accounts for more of the variance than the sum of the two taken individually.

27. In a regression on the performance index using as controls (1) the variable that combined "self-starting" and the jail rate into a single binary factor, (2) $\log _{10}$ population, and (3) the unemployment rate, the combined self-start/jailing factor had a coefficient of 14.77. Since the performance index is coded in percentage collected, the coefficient of 14.77 indicates that a county that had both a self-starting system and a high rate should collect after controls 14.77 percentage points more than those that did not have both. Since the mean collection rate among our counties was $65 \%$, an added 14.8 percentage points collected would represent about a $25 \%$ increase in collections for counties pushed from a mean collection rate of several percentage points below $65 \%$ to a mean rate of several points above. 
Payments go down with a larger population, up with a self-triggering warning system, down with more unemployment, and up with more jailings. Though our findings have surface plausibility, those who cherish life's complexity will be pleased that, when we peered deeper into our pool of data, we found the waters muddier than they initially appeared. The significance of the unemployment rate does seem to signify just what one would expect: those who are not working are likely to pay less or not at all. The significance of the three more powerful factors is less clear, however.

Our finding that counties with Friends of the Court that initiate enforcement without awaiting complaints collected more money than other counties is, at first glance, hardly perplexing. One anomaly nonetheless persists about this "self-starting" factor. We defined a "self-starting" county as one in which the Friend of the Court initiated enforcement efforts in nonwelfare cases without awaiting complaints from the custodial parent. We excluded welfare cases from the definition because all Friends of the Court had self-triggering systems for initiating enforcement in welfare cases, since the custodial parent in welfare cases is not the receiver of support payments and often does not know whether payments are being made. Given our definition, one would have expected that, when we analyzed the welfare cases from our samples in the 28 counties, the "self-starting" factor would not have helped sort the high- and low-collecting counties. In fact, however, the "self-starting" factor is nearly as significant an explanatory factor of the variations in the collections in the welfare cases as it is in the caseload as a whole, suggesting that the counties that are self-starting simply collect support in both welfare and nonwelfare cases more effectively, for reasons related to but distinct from the self-starting attribute alone. Several other attributes of the enforcement process-efficiency of bookkeeping, size of the enforcement staff in relation to caseload, and so forth-correlate mildly with performance and with the self-starting factor. It appears that "self-starting" may simply capture best the sum of the attributes of an efficient and persistent organization.

That organization to collect and the rate of jailing work hand in hand is also unsurprising. Under a self-starting enforcement system more men who falter are told to "pay up." The high rate of jailing seems to add, "and we really mean it." All rather tidy. We had expected, however, that the rate of jailing would not have been the only way to say "we really mean it," but at least within our study no other aggressive aspect of the enforcement system served anywhere nearly as well to explain the differences in overall collections. 
We looked, for example, at the use of orders to show cause, the orders to appear at hearings that are issued when men fail to respond to warning letters. We had a reasonably accurate count of such orders during the same period for which we counted jailings, and we found that counties varied widely in their rate of use of such orders and in the ratio of orders to subsequent sentences to jail. We had hypothesized that the rate of orders themselves, with their stern directive to appear in court, might well have served as a more effective indication than the sentencing rate itself of the seriousness of the enforcement agency. We found, however, that neither the rate of orders to show cause nor any combination of the show-cause rate and jail rate (to measure the conviction rate among those ordered to appear at hearings) helped sort the higher from the lower collecting counties nearly as well as the jail-rate alone. ${ }^{28}$ Within the range of measures that were readily available to us, the incidence of that which men actually fear-jail itself ${ }^{29}$-appears to communicate most effectively the necessity of paying their support obligations.

It is possible, nonetheless, that some unmeasured aspect of the enforcement process short of jailing better explains what the jailing rate appears to explain. We were, for example, unable to count the number of warning letters mailed in the twenty-eight counties during 1974 or any other year. We thus could not calculate the rate at which the agency sent warnings either in relation to the number of cases in the caseload or in relation to the number of cases with payments in arrears at some point during the year. The only information we could obtain about the average time between the development of an arrearage and the mailing of a warning was the agency head's statements regarding the policy of the office. While we believe it highly probable that our "self-starting" factor would correlate strongly and positively with each of these measures had we been able to develop them, the self-starting factor's form is not subtleevery county either was or was not "self-starting" in our definition. There were no gradations. It is thus possible that one or more of these other dimensions of the enforcement process would account

28. Whereas the product-moment correlation of the jail rate and the collections rate was +.492 , the correlation between the order-to-show-cause rate and the collections rate was only +.121 . When used with other variables or combined into other indices with the jailing rate, the show-cause rate offered virtually no explanatory power. Similarly, the combination of the sentencing rate with mean sentence length provided far less explanation of variations in payments than the sentencing rate alone and offered no significant explanatory power when used in a regression run with the jail rate as one of the other independent variables.

29. We used the jail rate in unaltered form and in logarithmic form, with closely similar results. See Appendix at the end of the article. 
for all or some part of the differences in collections that we have attributed to the rate of jailing.

A problem for analysis would persist even if we were to find within our twenty-eight counties that the jailing rate added nothing to the explanation of the variations in collections among counties, but that measures of milder enforcement efforts were powerful explainers of variation. Since the form letters of warning in nearly all counties carried threats of judicial action that many men probably read as a threat of jailing, a finding that nonpenal enforcement efforts, but not the jail rate, were a significant explainer of performance could have either of two very different meanings: it could mean that the threat of jail was truly irrelevant and that men can be propelled toward payments by reminders alone, or it could mean that letters threatening judicial action are sufficient in themselves to create the fear of jail, regardless of the actual rate of jailing. If the latter were the case, then, even though the actual jail rate was not a factor in collections, collections might well still decline if jail were removed as a legally permissible sanction and parents under orders of support learned of the change in the law.

The final significant factor apparently affecting collections was the county's population. Our findings suggest that, if two counties have a self-starting system of enforcement, jail at the same rate, and have the same rate of unemployment, the county with fewer residents $^{30}$ will still collect more money. Why should this be so? The lower collections in highly populated areas cannot be attributed to higher poverty there. On the contrary, the portions of the population living in poverty were higher, and median incomes appreciably lower, in the smaller Michigan counties than in the larger ones. ${ }^{31}$

The relevance of high population seems rather to lie either in attitudes of city dwellers about obligations to pay or, more likely, in a greater insulation of city dwellers from the enforcement process. In several of the small counties but none of the large, the director of the Friend of the Court knew personally most of the men in his county's caseload, a fact that probably affected some of the men

30. Since the counties in our sample vary little in geographic area, absolute population and population density correlated overwhelmingly.

31. For example, in the six counties in our sample with the smallest population, the median income (in 1970) and the unemployment rates during the months we surveyed averaged $\$ 9600$ and $12.5 \%$ respectively. By contrast, during the same periods median income and unemployment for the six largest counties averaged $\$ 11,900$ and $10.8 \%$ respectively. Similarly, in the six smallest counties the average portion of families living on incomes below the poverty line was $8.6 \%$, whereas the average portion in the six largest was $5.9 \%$. 
under orders. I walked with one agency head into a coffee shop on the town square in his county seat. He exchanged good-morning banter with several persons and then leaned over to me and whispered, "Now I'm not telling you who, but three of the men in here with us now are under orders in my office." The difference for the parent under an order in the smaller county is probably not merely that someone whose esteem he may value knows whether he is paying. It is also likely that he believes-correctly-that he is easily located. Staffs of the Friend of the Court in populous counties often reported severe problems of finding nonpayers, even when the defaulters had remained within the county.

\section{A Peek Inside: How Does Awareness of the Possibility of Jailing AfFect Payments WITHIN A COUNTY?}

Within our samples, ardent agencies collect more than the less vigilant. But how does this ardor exert its effect? Even in places with the laxest enforcement some men pay all the time. Even in places with the most terrorizing enforcement some men never pay at all.

Among questions that the reader may already be asking is whether the difference between the higher-collecting counties and the lower-collecting counties lies solely in the jailed men themselves: the high-collecting counties jail more men, jailed men pay better after release than they did before, and unjailed men pay at about the same mean rate in all counties. And if a fresh inspiration of those actually jailed does not account for the differences in collections among counties, how does the prospect of jailing work its black magic on the men who are never jailed?

We cannot fully answer these questions, but our close inquiry into two counties, one an ardent enforcer and the other not, permits us to say a good deal more than we otherwise could. When the remainder of our study is published, much of it will deal with the men within these two counties-their families, their financial situations, their payments, their treatment at the hands of the agency and the court, and their responses to all manner of enforcement efforts. Here we will address a couple of the questions especially invited by the discussion of general deterrence.

One of the two counties, Genesee County, where Flint is located, had a population in 1970 of 444,000 . Its Friend of the Court has long had a "self-starting" enforcement process, and its courts have long favored jail to punish defaulters. During 1974, Genesee County 
judges imprisoned 224 men for failing to pay support, a rate of 5 per 10,000 persons in the county, making Genesee one of the high-jailing counties. In a random sample we drew of over 400 divorced men whose cases were open in 1970, the men had paid an average of $74 \%$ of the total amount due over the lives of their decrees up to the point that we coded, a mean of seven years. Only $14 \%$ of the men had paid less than $10 \%$ of all amounts due under their decrees.

The other county, Washtenaw County, the county of Ann Arbor and Ypsilanti, was rather different. For most of this last decade, its Friend of the Court has expended a higher portion of its budget than any other Michigan county on social workers and other professionals concerned with marital counseling and child-custody matters. ${ }^{32} \mathrm{~A}$ much smaller portion of staff efforts was addressed to collections. Thus, it is perhaps not surprising, even if somewhat disheartening, that a random sample of about 400 men under support decrees in Washtenaw had paid on the average only $56 \%$ of everything due, over $25 \%$ less than the average portion paid by the Genesee men. This was true despite the fact that median earnings are higher in Washtenaw, unemployment lower, and the county population only slightly more than half as large. ${ }^{33}$ Over twice as many Washtenaw men $(30 \%)$ had paid less than $10 \%$ of their amounts due.

The enforcement systems in the two counties differed greatly. Two such differences are familiar to the reader. For several years up to and including the years we studied, Washtenaw had not been a "self-starting" county: a woman not receiving welfare benefits had to phone in a complaint before a form notice of arrearage was sent to the father and had to complain again, this time in writing, before a nonresponding father was sent an order to show cause. Moreover, though many Washtenaw men in the caseload had been arrested for nonsupport, often through the serving of a warrant when arrested for an altogether different offense like a traffic violation, Washtenaw's judges jailed far fewer persons for nonsupport. In the year that Genesee's judges sentenced 224 men, Washtenaw's sentenced only five.

32. The special orientation of Washtenaw's Friend of the Court is indicated by the scholarly writing that the head of the agency, Richard Benedek, has undertaken with his wife, Elissa, a psychiatrist. Sce, e.g., Benedek \& Benedek, Postdivorce Visitation: A Child's Right, 16 J. AM. ACAD. CHILD. PsYCH. 256 (1977).

33. Median income in Washtenaw in 1970 was $\$ 12,300$, whereas it was $\$ 11,300$ in Genesee; unemployment during the months we surveyed was under $5 \%$ in Washtenaw but over $11 \%$ in Genesee. In 1970, Washtenaw had a population of 234,000; Genesee a population of 444,000 . 


\section{A. The Role of the Jailed Men}

It is possible that men who are never jailed pay at nearly identical average rates in both high- and low-collecting counties and that the only reason one group of counties collects more is that men actually jailed, much more numerous in that group of counties than the other, are frightened into paying more regularly. This explanation, while plausible, does not appear to hold for our counties. The margin of difference in collections between the self-starting, high-jailing counties and others is too great to be accounted for by the small portion of the men in those counties who have both been jailed and begun and continued to pay after release. ${ }^{34}$

Moreover, it is simply not the case that the never-jailed men in the higher-jailing counties are unaffected by the policy around them and pay at essentially the rate of the never-jailed men in the lowcollecting counties. Everyone pays better in Genesee. Men sentenced, men arrested but never sentenced, and men never arrested all pay, as groups, significantly better in Genesee than their counterparts in Washtenaw. ${ }^{35}$ Whatever it is about the system in Genesee that induces men to pay reaches the jailed and unjailed men with similar effect.

34. During the one-year period we studied in the 28 counties, only a small portion of the men in the sample, even in the counties that jailed most heavily, had been jailed in the recent past. Even if we assume that this previously jailed group paid at the unlikely mean rate of $60 \%$ during the year we surveyed and further assume that had they not been jailed they would have all paid nothing (equally unlikely), their numbers are not substantial enough to have boosted the collective average of the whole county by more than a third of the difference we have computed to be the effect of the jailing policy.

As a matter of fact, in Genesee, the payment rate for our sample of jailed men was .33 in the year after their release; a comparable sample of jailed men in Macomb County paid at a rate of .50 . In the case of Genesee, the portion of the jailed men who maintained payments declined even further with the passage of time after release.

35. Our comparative data on Genesee and Washtenaw Counties, in table form, is as follows:

Comparison of Payments of Men IN TWO COUNTIES WHO WERE AND WERE NOT EVER ARRESTED OR SENTENCED FOR NONPAYMENT (Random Sample of Divorce Cases)

\begin{tabular}{|c|c|c|c|c|}
\hline . & $\mathbf{N}$ & $\begin{array}{c}\text { Washtenaw County } \\
\text { Average Payment } \\
\text { Rate Over } \\
\text { Life of Decree }\end{array}$ & $\mathbf{N}$ & $\begin{array}{c}\text { Genesee County } \\
\text { Average Payment } \\
\text { Rate Over } \\
\text { Life of Decree }\end{array}$ \\
\hline \multirow{4}{*}{$\begin{array}{l}\text { Men Sentenced to Jail } \\
\text { Men Arrested but } \\
\text { Never Sentenced } \\
\text { Men Who Were } \\
\text { Never Arrested } \\
\text { or Sentenced }\end{array}$} & 8 & .31 & $\overline{60}$ & .55 \\
\hline & 75 & .46 & 57 & .73 \\
\hline & 327 & .60 & 292 & .80 \\
\hline & 410 & .57 & 409 & .74 \\
\hline
\end{tabular}


Why do the men who are arrested or sentenced pay so much better in Genesee than in Washtenaw? One might have expected that jail would be equally chastening in both counties. Again, we cannot be completely certain of the reason. A partial answer may lie in the fact that the men arrested in Genesee had a smaller arrearage at the time of arrest. Men chastened earlier may respond better. Or, perhaps, as economists would predict, many jailed men ask themselves after release much the same question that the canny nonpayer asks who has never been jailed: not "how painful is jail?", but "how likely is it that I will soon (again) be arrested?" In Genesee, but not Washtenaw, the agency moved quickly against previously sentenced men who did not begin to pay. Indeed, when a Genesee man was in jail for the first time he would likely note that a significant portion of the other men there with him were persons who had been sentenced for nonsupport before; ${ }^{36}$ only one person in our Washtenaw sample had been sentenced twice. To be sure, people who have been jailed are not in an identical position with the never-jailed-once jailed, a man no longer has to imagine the discomfort or embarrassment of jail-but the tendency to regard the jailed and never-jailed men as different species, though inviting, is misguided.

\section{B. The Effects of Enforcement on Payments over Time}

As time passes after the entry of an order of support, some men cease to pay, some begin to pay, and some pay at the same rate. A comparison of the patterns of payment performance of fathers in Genesee and Washtenaw over the lives of their decrees sheds more light on the effects of a zealous enforcement process. Consider first Table 4, which shows for our random samples of men in each county the portion of men paying nearly nothing, paying nearly

36. In a sample we drew in Genesee County of 191 men jailed in 1969 and in the first nine months of 1970 , more than a quarter had been previously sentenced for nonsupport. On any given day, the portion of men in jail for nonsupport who had been previously sentenced was likely to have been even higher because the previously jailed men were typically held for longer terms. 
TABLE 4

COMPARISON OF PAYMENT RATES IN GENESEE AND WASHTENAW COUNTIES THROUGH SIXTH YEAR OF ORDER

(FOR CASES OPEN FOR AT LEAST THAT LONG)

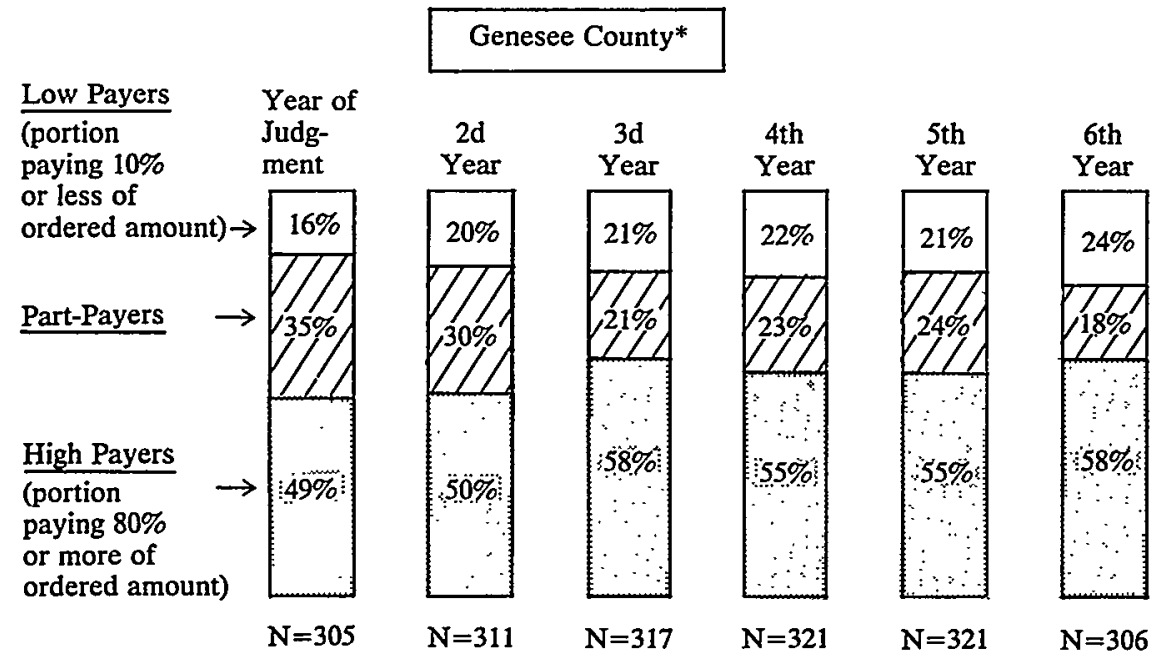

Mean of individual pay rates: $\quad .67$

$\begin{array}{lll}.66 & .69 \quad .70\end{array}$

Washtenaw County

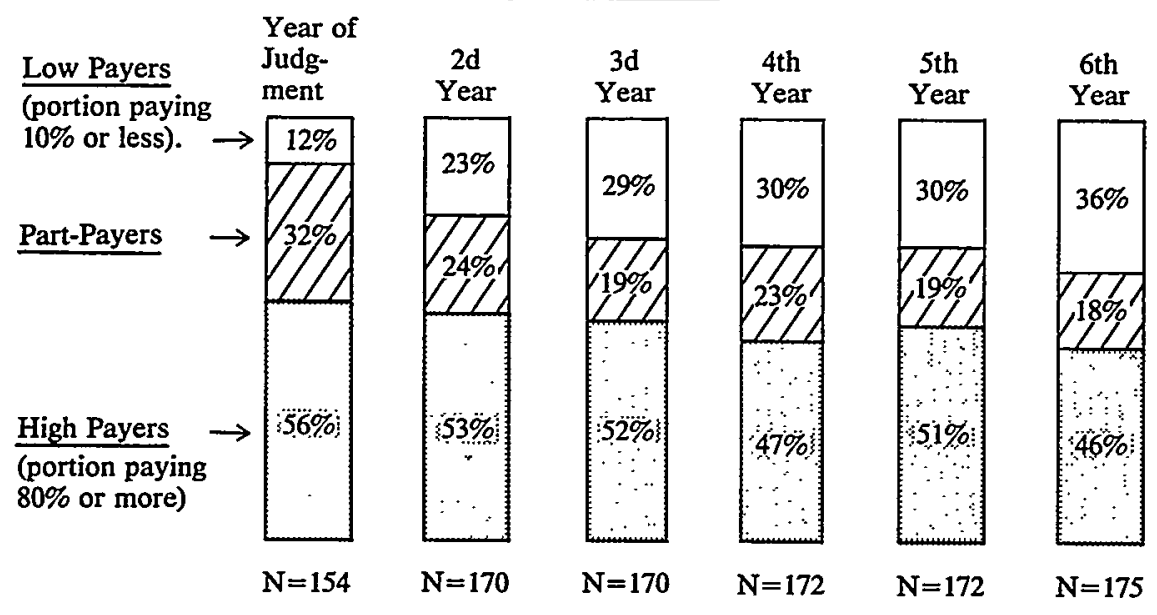

Mean of individual pay rates: $.70 \quad .65$

.61

.60

.60

.53

* In this table, we have made an adjustment for a small group of low-paying cases opened prior to 1966 , when the Friend of the Court in Genesee put its payment 
everything, or paying somewhere in between year by year after the entry of the decree.

In the first year in each county most men pay either nearly everything or nearly nothing, and over the years, quite predictably, more and more men are found at the extremes. The difference between the two counties, subtle but distinct, lies in the portions paying at high and low rates. In Genesee in the first year, of every twelve men, six are high payers and two are low payers. By the sixth year, seven are high payers and three are low payers. ${ }^{37}$ The mean level of payments rises slightly over the years, up to .72. In Washtenaw, the pattern is better than Genesee in the beginning but worse at the end. In the first year, seven of every twelve men are high payers and only between one and two are low payers. By the sixth year, however, the portion of high payers has declined to five of twelve and the portion of low payers has risen to over four in twelve. The mean level of payments in Washtenaw falls somewhat every year, ending at .57. Were we able to control for population and unemployment, the earlier results suggest that Washtenaw, both smaller and with less unemployment, would appear even worse.

The distribution of payments in the two counties over time suggests that in each county a substantial number of men consciously or unconsciously test the enforcement system in the early years. In Genesee a significant number are "burned" and move toward full payments. In Washtenaw, many who paid nearly in full or in part in the first year move toward nonpayment after finding either that a period of haphazard payments is ignored or followed by hollow threats or that, even if they are arrested, they are soon released and forgotten. Our findings regarding the use of warning letters and the responses to warnings in Genesee corroborate these conclusions.

Standing next to Genesee's system, Washtenaw's may seem largely ineffectual. In fact, however, the presence in Washtenaw of a fulltime agency has significant effects on collections that can be appreciated by comparing Genesee and Washtenaw with a jurisdiction in

records on computer. By examining all orders set by the courts in 1960 and 1963 , we have determined that about $7 \%$ of cases opened in those years had been closed by 1966 for consistent nonpayment without request for enforcement. In the adjustments we have made, we have increased the total cases to reflect an additional number of cases presumably closed and placed all such assumed closed cases in the "no payments" column. The effect is slight. For the six years reprinted here, the actual number of files prior to the adjustment is 15 fewer than reported above in the first and last years and 16 fewer than reported above for the years in between.

37. The patterns in each county were actually somewhat more complex than these figures suggest since the figures represent only net movement. Few men, however, shifted from one bracket to another and back again. 
which there is no systematic enforcement system at all. In the mid1960s, Kenneth Eckhardt conducted a study of child-support collections in Dane County, Wisconsin. ${ }^{38}$ This county, containing both the state capital and the main campus of the state university, was as prosperous as Washtenaw and Genesee and was substantially smaller than Genesee in its population. ${ }^{39}$ In Dane, though an office of the court collected child-support payments and forwarded them to the wife, the agency played no routine role in enforcing orders and had no staff devoted to reminding men of their default. The mother who was not receiving payments had to find an attorney and pursue private remedies. Most defaulters were left completely alone. On the other hand, substantial numbers of men were prosecuted and jailed for nonpayment not as a capstone of a well-focused effort to enforce support but largely, it appeared, as a part of the enforcement of other laws: most of the jailed men seem to have been wanted by the prosecutor for committing other offenses not as easily proved. ${ }^{40}$

Table 5 contains information on the payment levels in the Wisconsin county and how they changed over time. The differences from our Michigan counties are startling. In Dane, as in our Michigan counties, a large portion of the men paid nearly all amounts due in the first year, but, whereas this full-paying group shrank only slightly over time in Washtenaw and grew over time in Genesee, the full-paying group in Dane shrank steadily and rapidly. By the sixth year only $17 \%$ of the caseload was paying in full. Moreover, the portion of men paying nothing began at a much higher level in Dane-nearly $40 \%$ paid nothing in the first year, in contrast to the nonpayment rate in the first year of around $15 \%$ in each of the two Michigan counties. By the sixth year, the group paying nothing in Wisconsin grew to $71 \%$ of the caseload.

38. K. Eckhardt, Social Change, Legal Controls, and Child Support: A Study in the Sociology of Law (unpublished dissertation, University of Wisconsin 1965). Parts of the results of his study are also to be found in Eckhardt, Deviance, Visibility and Legal Action: The Duty To Support, 15 Soc. ProB. 470 (1968).

39.

Population

Per cent of labor force unemployed

Median family income

Portion of workerswhite collar 1970 Census Figures

\begin{tabular}{ccc}
\multicolumn{2}{c}{1970 CENSUS FIGURES } \\
$\begin{array}{c}\text { Dane County, } \\
\text { Wisconsin } \\
290,000\end{array}$ & $\begin{array}{c}\text { Genee County, } \\
\text { Michigan }\end{array}$ & $\begin{array}{c}\text { Washtenaw County, } \\
\text { Michigan } \\
244,000\end{array}$ \\
$2.9 \%$ & $5.3 \%$ & 234,000 \\
$\$ 11,300$ & $\$ 11,300$ & $5.0 \%$ \\
$59 \%$ & $38 \%$ & $\$ 12,300$ \\
& & $56 \%$
\end{tabular}

See United States Bureau of the Census, County and City Data Book, 1972 at $234,236-37,522,524-25$ (1973).

40. K. Eckhardt, supra note 38 , at 261-65. 


\section{TABLE 5}

\section{Distribution OF PAYMENTS BY DivORCED FATHERS \\ IN DANE COUNTY, Wisconsin THROUGH \\ SIXTH YEAR AFTER DIVORCE*}

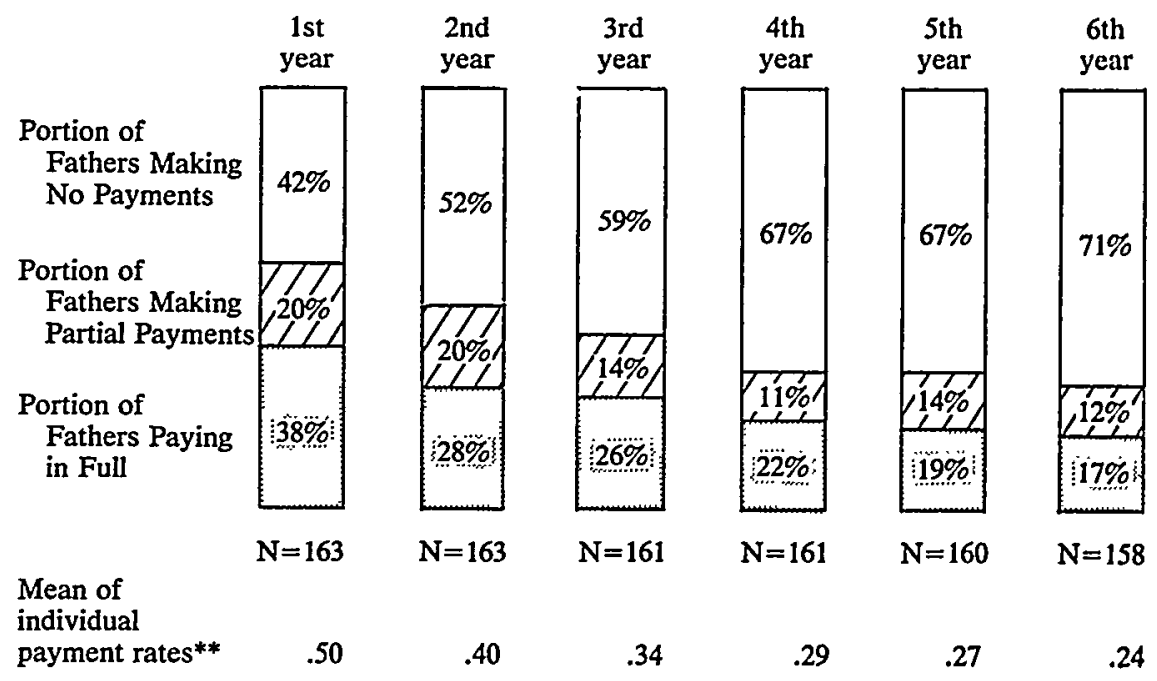

* Data from K. Eckhardt, Social Change, Legal Controls and Child Support: A Study in the Sociology of Law 226 (unpublished dissertation, University of Wisconsin 1965).

** Computed by ascribing $100 \%$ as payment rate of full payers, $0 \%$ as payment rate of nonpayers, and $60 \%$ as the rate of partial payers.

Because of the similar socioeconomic conditions in the three counties, two conclusions are invited by a comparison of their rates of collections. The first is that the presence of a full-time enforcement agency in Washtenaw, ready, if requested, to make efforts at enforcement, exerts significant and sustained effects on many fathers' payments throughout the lives of their orders.

Our conclusion that even a minimal, full-time enforcement system such as Washtenaw's Friend of the Court has a significant impact on collections is corroborated by the information collected annually by the Department of Health, Education, and Welfare on support payments in welfare cases in each of the fifty states, many of which, until recently, made no organized effort to collect support even in welfare cases. Year after year, up through the mid-1970s, Michigan apparently collected an average of more per case than any other state in the country. ${ }^{41}$

41. See, e.g., Staff of the Senate Comm. on Finance, 94th Cong., 1st Sess., Child Support: Data and Materials 151 (Comm. Print 1975). Washington and 
The second conclusion suggested by comparing the Michigan and Wisconsin data concerns the effects of jail as an instrument of enforcement. We found within Michigan that, in the absence of a selfstarting enforcement system, a heavy jailing rate makes little difference in collections. The experience of the Wisconsin county, collecting so little but jailing as many men as Genesee, bolsters our own tentative conclusion about the futility of jail as an instrument of collection unless it is perceived by potential offenders as likely to occur to them, a belief that apparently arises not from the mere occurrence of jail but from an effective reminder system well marked with road signs pointing toward confinement.

\section{IMPLications of THE STUDY FOR Collection OF CHILD SUPPORT}

An aggressive enforcement system, capped by jailing, induces many men to pay who otherwise would not. Working men who willfully refuse to support their children are widely considered immoral. On these two grounds alone, most Americans would probably consider jailing for nonsupport justifiable, even desirable. Before embracing jail too warmly, however, several further questions need answers: Do the dollar costs of a self-starting enforcement policy that relies in part on the use of jail exceed the dollars in added returns? Are there other costs to a jailing policy that cast doubt on the wisdom of relying on it? And finally, are there alternative systems not relying on jailing that can yield results that are as good as or better than those generated by jailing?

\section{A. The Dollar Costs and Benefits of Ardent Enforcement}

The answer to the first question-do dollar costs of especially aggressive enforcement exceed dollar benefits-seems to be a clear "no." The financial costs of a self-starting, high-jailing system-of extra enforcement officers, extra court time, jail operations, and so forth-are considerable, but the additional amount of support collected is simply greater. As we discussed above, within the Michigan study, counties with both a self-starting enforcement policy and a substantial reliance on jailing collected on average $25 \%$ more than counties that did not have both, after controlling for population and unemployment. Thus, in Genesee County the marginal dollar costs of the arresting, jailing, and self-starting policy in 1974 might

California also have highly organized systems for collection in welfare cases. Because some data are missing, it is possible that in some years Washington collected as much or more on the average as Michigan. 
conceivably have been as high as $\$ 500,000,{ }^{42}$ but the amount of collections attributable to these enforcement efforts might have been nearly $\$ 3.5$ million of the more than $\$ 17.3$ million collected by the agency that year. ${ }^{43}$

We have so far been comparing costs and benefits among counties with full-time agencies, some more strident than others. If we compare instead the probable costs and returns of two jurisdictions, one having a full-time aggressive agency and the other having no agency at all and leaving each parent to private devices, by hypothesis, the savings in enforcement costs would be even greater for the latter. Yet, as the Dane County, Wisconsin, study suggests, ${ }^{44}$ we would almost certainly find that the foregone collections would be vastly greater yet. ${ }^{45}$

Our calculations do not include conceivably determinable losses of wages by the men jailed or losses of tax revenues from them, but these losses, while not trivial, need not necessarily be great. If, as

42. More work remains to be done by us on the marginal costs of a jailing policy. As usual, numerous factors complicate the calculations. For example, each Genesee judge spent a few hours a week on child-support cases, but removal of these cases from the dockets would not have led to a reduction in the number of judges. The long average jail terms in Genesee must have inflated enforcement costs, but a portion of these costs were probably avoidable without any loss in collections since, within the counties in our study, neither the length of the sentence nor the amount of time served affected county collections. Our calculation that Genesee incurred marginal costs of $\$ 500,000$ in order to sustain an aggressive, high-jailing system is based on a generous estimate of the expenses. Viz., we assumed that a shift to a passive enforcement system would have allowed a reduction of one-half in the size of the enforcement staff and a savings of $\$ 100,000$ in court time. We further assumed that the average jail term served would be 60 days (far longer than that in most highcollecting counties) and that the costs of jailing were $\$ 10$ per inmate per day, the figure used by the Genesee sheriff in preparing his 1974 budget. Even with these highly inflated figures, costs barely totaled $\$ 400,000$, while in 1974 Genesee's Friend of the Court collected $\$ 17.3$ million.

43. Given our finding that a high-jailing, self-starting enforcement system boosts collections by roughly $25 \%$, see text at note 27 supra, Genesee's collections in 1974 would have been about $\$ 13.8$ million, rather than the $\$ 17.3$ million actually collected, but for this system.

44. See text at and following notes 38-40 supra.

45. See also Comptroller General of the United States, Collection of Child Support UNder the Program of Aid to Families with Dependent ChilDREN (1972) (report to the House Committee on Ways and Means).

A study of child-support collections that has been done for the Department of Health, Education and Welfare in five places with ardent enforcement procedures in welfare cases (including Genesee County, Michigan) found that in all of them the returns in dollars collected vastly exceeded the dollar cost of the enforcement efforts. See U.S. Dept. Of Health, Education and Welfare, Absent Parent Child Support COST-BEnefit ANAlysis (1975). The study was conducted by Arthur Young \& Company. This study did not compute the costs of jailing. On the other hand, it included all the costs of a bookkeeping and enforcement system in both divorce and paternity cases. 
other parts of our study suggest, the deterrent effect of the sentencing rate turns not at all on the length of sentences imposed nor on the number of days served (some of the highest-collecting counties imposed the shortest sentences), most men could be held only a day or two with loss of little, if any, of the general deterrent effect.

We must remember when we are comparing costs and benefits that we are often referring to costs to the taxpayers to produce benefits to individual families. Only in welfare cases does the government both bear the costs and reap the gains and, even in the welfare setting, federal, state, and local governments bear uneven shares of the costs in relation to their shares of the returns. ${ }^{46}$ In nonwelfare cases, dollars collected by the state are sent on to the custodial parent. At any given time, most divorced parents with children are not receiving welfare benefits. Across our twenty-eight counties, an average of $30 \%$ of the families were receiving welfare at the time we sampled. For the $70 \%$ of families not on welfare, the relevant cost-benefit question differs from that appropriately asked when the government is collecting for itself: in a society that normally relies on private ordering, the question is whether public enforcement offers values over private enforcement sufficient to justify the expenditure of public funds. Because public enforcement is so much more effective and because so many dollars are at stake for the benefit of children, most Americans would probably answer "yes," but reaching such an answer does require more than simply counting dollars. ${ }^{47}$

\section{B. Other Costs of a Jailing Policy}

Even if a jailing policy yields more dollars than it costs, there may well be other reasons for doubting the wisdom of reliance on jail as an instrument of enforcement. An initial doubt about jailing for nonsupport is jurisprudential in nature. We might well decide that even willful nonsupport is not one of those forms of human misbehavior appropriately dealt with by criminal sanctions. Though not one of the "victimless" offenses, it is nonetheless an intra-family offense often signifying the continuation after divorce of patterns of behavior that were a part of the marital relationship: withholding as a technique of communication. Divorced men often "forget" to pay

46. See, e.g., Title IV(D) of the Social Security Act, 42 U.S.C. $\S \S 655,658$ (Supp. V 1975).

47. To some degree the costs of public enforcement can be passed on to the "consumer." In Michigan, for example, each person subject to an order of support is charged $\$ 18$ a year to offset part of the agency's operating expenses. 
not out of vicious disregard for their children but from more prosaic human failings of jealousy or anger. Divorced women may similarly "forget" that Tuesday was the day the father was coming to visit the children. Citing the "emotional stress" of the post-divorce period and child support's connection with "an intimate personal relationship," the Committee on One-Parent Families of Britain's Department of Health and Social Security thus recently recommended that Parliament eliminate jail as a permissible sanction for nonsupport. ${ }^{48}$

Although the British Committee apparently assumed, contrary to our findings in Michigan, that neither jailing nor the threat of jailing produces beneficial effects on parents' payments, the Committee's judgment about the inappropriateness of penal sanctions in this context has appeal nonetheless. To be sure, the fact that behavior occurs between family members should not by itself place it beyond the reach of the criminal law. Few would recommend removing penalties for the killing of one spouse by another, even though it is connected with "an intimate personal relationship" and committed under "emotional stress." To most people, however, killing and nonpayment of support are simply not of the same order of seriousness. Thus, recognizing the emotional stress that lies behind the failure of many men to pay support may undercut our sense that the act should be considered criminal and the offender marked with our most severe form of public condemnation, even though the same degree of stress would alter only slightly our sense of the heinousness of murder.

Examining the men who end up in jail provides a second source of misgivings about using it widely. Most of us have probably growled over news accounts of a physician or insurance agent earning $\$ 60,000$ but failing to make his support payments. Well, few doctors or insurance agents languish in Michigan jails for failing to pay child support. The hundreds of men found in Michigan's jails on any given day typically have unsteady work histories as unskilled workers. A high portion have alcohol problems. ${ }^{49}$

48. 1 Department of Health and Social Security, Report of the Commit. TEE ON ONE-PARENT FaMiLIES 128-32 (1974).

49. In our sample of 191 men sentenced to jail in Genesee County in 1969 and 1970, over two-thirds had indications in their file-wife's complaints, arrests for alcohol offenses-of some sort of alcohol program. Half of this group had two or more such indications in their files. In a mail survey of the 28 Friends of the Court in our study, 18 answered a question asking whether there were any "recurrent patterns" among the men sentenced to jail for nonsupport in their county: 13 of these mentioned alcoholism or alcohol problems as one recurrent characteristic among their jailed men. 
The agencies do not wink at nonpayment by the doctor; rather, the doctors who fail to pay are more likely, if jail is imminent, to have access to sufficient cash to appease the agency. Several aspects of the skewed population in the jails should give us pause. To the extent that we punish the unskilled worker in order to produce higher payments from thousands of higher-income fathers, we are repeating a familiar and dubious pattern in our society that finds its analogues in the use of jailing for street-corner gambling as well as in medical experimentation on prison inmates. To the extent that we punish the blue-collar workers because we are angry at them themselves, our anger is sometimes misplaced. While most of the men jailed could, in the literal sense, have paid more than they did, many see themselves, with some justification, as barely making do, scraping the sides of the bowl of thin gruel provided the least-skilled workers in our society. We blame such men and their supposedly footloose ways for the rise in the welfare rolls, just as some persons in the eighteenth century viewed those who did not pay their bills as a cause of the decay of civilized society. Jailing for nonsupport is a twentieth-century form of jailing for debt. ${ }^{50}$

A third and more tangible reason for avoiding criminal sanctions for nonpayment of support is the conditions of our jails. America's county jails are among our most vicious institutions of incarceration. ${ }^{51}$ Often jammed with far more inmates than they were built to hold, they rely on forced inactivity and breed bodily and sexual assault. The character of our jails should be seen as particularly troublesome in this setting when we recall the high level of jailing in many of Michigan's counties. Judges sentence close to 4,000 Michigan men each year for nonsupport. In several counties their numbers outstrip by far the number of men sentenced to jail for drunken driving or larceny offenses. It is probable that each year at least 1,000 more Michigan men under support orders spend a day or so in jail under arrest without later being sentenced. While many sentenced men serve no more than a day or two, it is still alarming that we label as criminal one in ten or one in twelve of all divorced noncustodial

50. See P. Rock, Making MEN Pay 307-16 (1973) (tracing the use of jailing for debt in 18th and 19th century England).

51. "Life in many institutions is at best barren and futile, at worst unspeakably brutal and degrading .... No part of corrections is weaker than the local facilities that handle persons awaiting trial and serving short sentences." PREsIDENT's COMmission on LaW ENForCement and Administration of Justice, The ChaiLENGE OF CRIME IN A FREe SOCIETY 159, 178 (1967).

See also R. GoldFarb, JAILs: ThE Ultimate GhetTo (1975); Mattick, The Contemporary Jails of the United States: An Unknown and Neglected Area of Jus- 
parents at some point during the life of their support orders. ${ }^{52}$ Studies in other settings have shown well the long-term scars that can develop from labeling people as criminal deviants. ${ }^{63}$ If Michigan's aggressiveness were replicated in the rest of the country, as might conceivably occur under the new pressures for collection the federal government is applying in welfare cases, we could find courts sentencing 100,000 American parents for nonpayment of support each year.

Frequently men who have been jailed flee the county upon release. $^{54}$ We have little way of measuring how many other men, never jailed, leave because they fear that jail may befall them, although that group also appears to be substantial in number. ${ }^{65}$ Since those who leave because of such fears may well be men with a strong desire not to pay, it is unclear how many of them would have continued a relationship with their children if they had remained in the county. Jailing may nonetheless damage the quality of the relationship between parent and child, even when the father does continue to visit and pays support regularly. What is the impact of an everpresent threat of jail on the relationship between a noncustodial par-

tice in HaNdBOOK IN CRIMINology 777 (D. Glaser ed. 1974). County jails typically include a mix of persons under sentence for misdemeanors (such as drunkenness) and persons awaiting trial for serious felonies who cannot make bail.

52. In Genesee, approximately one of every seven men in the active caseload in 1970 had been sentenced to jail at least once. Table 2 in the text shows that in 28 Michigan counties 3046 men, or $1.05 \%$, from a total caseload of about 290,000 were sentenced to jail in 1974. However, the number of men in the caseload who have ever been jailed is much higher, since most men sentenced in one year remain in the caseload for succeeding years. A case typically will last 12 to 15 years, from divorce to the 18 th birthday of the youngest child.

53. See H. Becker, Outsiders: Studies in the Sociology of Deviance 31 (1963): "One of the most crucial steps in the process of building a stable pattern of deviant behavior is likely to be the experience of being caught and publicly labeled as a deviant." See also R. ScotT \& J. Douglas, TheOretical Perspectives oN Deviance (1972); The Labeling of Deviance: Evaluating a Perspective (W. Gove ed. 1975).

54. In a sample we drew of 191 men sentenced to jail in Genesee County during 1969 and 1970, over one-third (61 of the 172 whose records were complete and whose cases remained open for another year) fled town within a year after their release from jail. We use the verb "flee" here because the payment rate in the year after the release of those jailed persons who leave town is so low (.09) in comparison to those jailed persons who stay (.48) that, for most, avoidance of jail seems to have been a primary motive for their leaving town.

55. In our random sample of 411 divorced families in Genesee County, 70 fathers appear from our records to have moved away from the county after divorce. If this group had paid at roughly the same rate as those who stayed, we could make no inferences about their motive for leaving. In fact, this group paid so much less well than those who appear to have stayed (a mean payment rate of .35 as opposed to a mean of .82 ) that it seems highly probable that many left to avoid the enforcement system. 
ent and his child? How, that is, does a parent begin to behave toward a child to whom he feels tied not by affection alone but at least in part by fear? Can jail's distant possibility make even more tense the already awkward visits between parent and child after divorce? Can it aggravate the injuries to the child's development?

Since little research exists on the impact on children's development of various patterns of relations between the child and noncustodial parent after divorce, ${ }^{56}$ it is hazardous to speculate on the particular effects that the prospects of jailing could have. In many cases, perhaps most, my worries may well be groundless. Many fathers may be induced into regular payments in part through vague awareness of the jailing policy but form a habit of payment so routine that they soon cease altogether to be affected by the dire consequences of ceasing to pay. For them, the jailing policy may indirectly improve rather than corrode the relation with their children by removing friction between the divorced parents over erratic payments.

\section{An Alternative to Jail: Deductions from Wages}

Even if one concluded that the benefits of a jailing policy greatly exceeded all these possible social costs, jailing might still be wisely avoided or curtailed if an alternative method of enforcement exists that can produce as much or more money with lower costs. Such an alternative may well be available. In the United States, child support and taxes are the only personal financial obligations routinely enforced by public agencies. For the collection of income and Social Security taxes, Americans are well accustomed to the withholding of wages. "Wage assignments" for child support operate similarly when imposed on an employer and are authorized by law in Michigan and several other states. In most states, including Michigan, however, courts may not impose a wage assignment except on a person already in default, ${ }^{57}$ and in all states a wage assignment ends

56. Parts of the results of a University of California at Berkeley study of children of divorce will be appearing in the summer of 1977. Kelly \& Wallerstein, PartTime Parent, Part-Time Child: Visiting After Divorce, J. of Clinical Child Psych. (Summer 1977). See also Benedek \& Benedek, supra note 32.

57. Compare MD. ANN. CODE art. 27, § 88 (1976) and MICH. CoMP. Laws $\$$ 522.203 (1970) (both requiring default before imposing a wage assignment) with WIS. StaT. $\$ 247.265$ (1973) (permitting wage assignment to be imposed "at any time.") See also 42 U.S.C. $\$ 659$ (Supp. V 1975), by which Congress recently provided that wage assignments for support of children would be honored for employees of the United States government as if the United States were a private employer. Thus, if state law permitted, a United States employee could be subject to an involuntary wage assignment without proof of default. 
when a person ceases to work for the employer against whom it was ordered.

If a federal system were established under which withholding occurred from the first moment of an order and traveled with a person wherever he took work within the country, the need for much of the current enforcement system would largely disappear. To effectuate this network, the federal government would need to create a national computerized system tied to the man's Social Security number. Employers would be required to make a check on a new employee through a Social Security office to learn whether support payments were to be withheld from his wages. Under such a system, the frequency of payments would be nearly perfect except by the unemployed, ${ }^{58}$ the self-employed, and those able to evade the floating wage assignment by falsifying their social security numbers or by colluding with the employer. ${ }^{59}$

A compulsory deduction system would, to be sure, have many troublesome aspects. It would be cumbersome to administer, a fountain of details inviting errors. Unlike income-tax withholding, deductions for child support would be required only for certain employees, who would not look any different at the time of hiring from other new employees. Unlike income taxes, support payments would generally have to be funneled to a recipient other than the federal government, a process likely to take several weeks, even months. ${ }^{60}$ At varying intervals, as children reached majority, the amount to be withheld would change.

58. No sanctions should ever be imposed on unemployed men without other income. In Genesee, many unemployed men were jailed after a finding that they could have been working, a chimerical finding in a nation with over $7 \%$ unemployment. A few men are willing to starve themselves to avoid paying support, but their numbers are worth neither the effort to ferret them out, nor the injustice to those who are unemployed for reasons beyond their control.

59. An additional advantage of the assignment system is that it would allow the court to fix orders in terms of a percentage of the individual's net earnings, rather than following the universal practice of defining the order as a fixed dollar amount based on the individual's income at the time of the divorce. Although courts have the power to modify an order to reflect changes in earnings, the procedure is cumbersome and in many places infrequently used.

60. Presently, employers pay Social Security taxes quarterly. If, under the system envisioned here, employers had to forward support withholdings only once a quarter, some support payments would remain in the employers' accounts for over three months. Even if employers were required to forward payments weekly, the forwarding would likely be to a single federal office, which would in turn forward the amount either to the custodial parent, to a welfare department, or to another forwarding agency such as a Friend of the Court. The record of sloth and error in the Social Security Administration's handling of old-age and disability benefits is hardly encouraging. 
The drawbacks of a compulsory wage-assignment system would not be solely ones of administration. Such a system would also curtail individual liberty. Many people feel strongly about their right to decide for themselves what to do with their earnings. They would resent involuntary wage assignments for child support as much as they would resent involuntary deductions for their utility bills, even though they would agree that it was reprehensible not to pay their bills. Whether seen as a right or an obligation, many noncustodial parents attach importance to their weekly voluntary writing of a support check, viewing it as a means to demonstrate their love for their children. ${ }^{61}$

A wage-assignment system would also involve another sort of federal intrusion on privacy. We can appropriately worry about a federal computer system carrying detailed information about the failed marriages of millions of citizens. Indeed, the employers would invariably learn through the system that their employee was divorced or the parent of an illegitimate child. Today, agencies often hesitate to impose wage assignments in cases in which they fear that the father is likely to be fired because his employer either does not want the bother of making an additional deduction or thinks ill of a person who is divorced or the parent of a "bastard." This troublesome problem of employer attitude could well continue under the system proposed here.

For all these reasons, it is easily understandable why only a bare majority of the Friends of the Court indicated in a mailed survey that they would favor a change in Michigan law to permit the imposition of a wage assignment at the moment the support order first takes effect, despite the fact that, as a group, they are strongly committed to improving collections of support. ${ }^{62}$ In the end, however, the issue is not the evil of such a wage deduction system in the abstract. Rather, it is whether it is better or worse than the sin-based system that we have now-the system in which we dangle before men the opportunity not to pay, often so inviting because of the pain of continued recollection of the old family and the burdens of new ex-

61. This observation is based on field interviews with staff members of Genesee County's Friend of the Court during the summers of 1972 and 1973 . From those interviews, we also learned that men often view the wage assignment with disfavor because it curtails their bargaining power in the post-divorce period. In the absence of a wage assignment, they can retaliate by slowing up on payments when the custodial parent reneges on visitation. When a wage assignment is in effect, they can retaliate in the same way only by quitting their job.

62. Twenty-three Friends of the Court among the 28 in our study responded to our questionnaire. Of the 23,12 favored such a change in the law, one was neutral and 10 opposed. 
penses, and, then, when men respond to the opportunity, clap them into jail.

If state and federal governments remain committed to compelling long-absent parents to support their children and determined to enforce the obligation aggressively, I for one would choose the compulsory deduction system over the system now found in Michigan. The deduction system would be my preference not so much because it would almost certainly lead to even higher collections than Michigan obtains today, but rather because of the doubts $I$ have expressed about the justness of a jail-based system and about the atmosphere that system creates. The choice may seem easier because the new system does not yet exist. It is, however, hard to believe that a new system, however intrusive, could be as distasteful as one that depends heavily on imprisonment and the fear of imprisonment. If you have any doubts in this regard, turn yourself in for a weekend at your nearest county jail.

Another alternative to the heavy use of jail exists. It is simply for states to create efficient full-time enforcement offices, comparable to Friends of the Court, with courts empowered to use sentences to jail but rarely actually doing so. Remember that in eight of our counties, the judges jailed few people but the full-time agencies in each still collected vastly more than Dane County, Wisconsin. To those to whom jail is repugnant or at least distasteful, this is a possible middle ground that could lead to much higher collections in the many places that now leave mothers not receiving welfare to the same inadequate private remedies available in Dane.

\section{The Implications of the Study for EFforts To Control Other Forms of UNdesirable BeHavior}

If the use of jail deters nonpayment of support, can we conclude that it will similarly deter rape or armed robbery? Of course not. We can expect that jail will have a greater effect when men know that all their actions are observed. Most armed robbers and rapists hope that their identity will remain unknown. Most shoplifters and heroin sellers hope that even the offense itself will never be detected by anyone interested in securing an arrest. In the case of child support in Michigan the fact of the offense and the identity of the perpetrator are always known. Thus the very factor that made our study possible - the all-knowing files of the Friend of the Courtmakes our findings ungeneralizable to most other forms of conduct. ${ }^{08}$

63. For a provocative discussion of the quite different problems of deterring 
In addition, each form of behavior has its own psychological setting. Persons considering aggressive sexual or physical assaults, even if they know that their identities will be learned, may well be typically less responsive to the threat of incarceration. Nonpayment is not an irreversible act committed in the heat of passion. However angry a man may be at his former wife, a "sudden" decision on Tuesday not to pay can be fully undone and punishment ayoided on Wednesday or even a week from Wednesday, after reflecting on the consequences of default.

Most men do not, of course, deliberate each week about payment or nonpayment. Penal sanctions may operate in a much more subtle way to reinforce a person's sense of how much importance the community attaches to a certain form of behavior. In the context of child support, we have been unable to determine the contribution of jailing to this socialization process, and our inability to measure this and compare it with other forms of behavior further reduces the utility of our study for understanding such other forms of behavior.

Despite all these cautions, the study does seem to confirm one commonplace prediction: swift and certain punishment can reduce the incidence of some forms of undesired conduct so long as potential offenders perceive a clear link between their own behavior and a system that leads to punishment. If a policeman is watching and customers know it, fewer candy bars are stolen. The sad finding of our study has been that, in the absence of sanctions, so many fathers fail to pay. The striking finding has been the effectiveness of enforcement agencies in many Michigan counties in creating a sense of a policeman at the elbow.

"street crime," see N. Morris \& G. Hawkins, The Honest Politiclan's Guide to Crime Control (1970); J. Wilson, ThinkIng About Crime (1975). 
APPENDIX

Regression Analysis of Factors Accounting for Differences

in Rates of Collections Among Twenty-Eight Counties.

The measure of county performance used in the study was the mean for each county of the individual payment rates for each person in the sample for the period sampled. That measure is referred to here as the "Mean Payment Rate." For the manner in which the individual rate was computed, see note 12 supra. This measure was used as the dependent variable here either in its natural form, its log to base 10, or its "Logit" form, as indicated.

A list of around 40 control variables tested in the analysis can be obtained directly from the author. Below are the controls used in the analyses reported here:

1. Self-Starting Factor. A binary variable that records whether (coded 1) or not (coded 0 ) the county has used for several years an enforcement system in which the agency initiates enforcement in nonwelfare cases without awaiting complaints from the mother.

2. Jailing Rate. The number of sentences to jail in 1974 for contempt of court for nonpayment of support for each 10,000 persons in the county population. As explained in note 17 supra, this rate closely parallels the rate of jailing for each 250 men in the county caseload.

3. Population. The $\log _{10}$ of the county's population from the 1970 decennial census.

4. Unemployment Rate. The unemployment rate in the civilian labor force according to the 1970 census. A further explanation of our use of the unemployment figures is found in note 25 supra.

5. High-Jail/Self-Start Factor. A combination of factors 1 and 2 above into a binary variable that coded whether or not a county was both high jailing and "self-starting". Those counties that had both a jail rate of 4 or more per 10,000 and a self-starting system were contrasted with all other counties. The selected rate of 4 per 10,000 divided our counties approximately at the median and had no other conceptual foundation.

6. Jail $x$ Self-Start Factor. Factor 1 above multiplied by Factor 2. The multiplication produced a 0 for all counties without a selfstarting policy (regardless of their jailing rate) and their jailing rate (from 1 to 17 ) for all counties that did have a self-starting policy. 


\section{A. Regression on the "Mean Payment Rate"}

1. With three variables that explain most variance:

\begin{tabular}{|c|c|c|c|c|}
\hline & B & Beta & T-Ratio & $\begin{array}{c}\text { Signif- } \\
\text { icance } \\
\text { Level }\end{array}$ \\
\hline $\begin{array}{l}\text { Self-starting Factor } \\
\text { Jailing Rate }\end{array}$ & $\begin{array}{l}\overline{8.62} \\
0.92\end{array}$ & $\begin{array}{l}\overline{+0.41} \\
+0.35\end{array}$ & $\begin{array}{l}2.89 \\
2.64\end{array}$ & $<.01$ \\
\hline $\log _{10}$ Population & -7.91 & -0.34 & 2.53 & $<.02$ \\
\hline
\end{tabular}

Fraction of explained variance: 62.6 per cent (unadjusted)

57.9 per cent (adjusted)

2. With four variables that explain most variance:

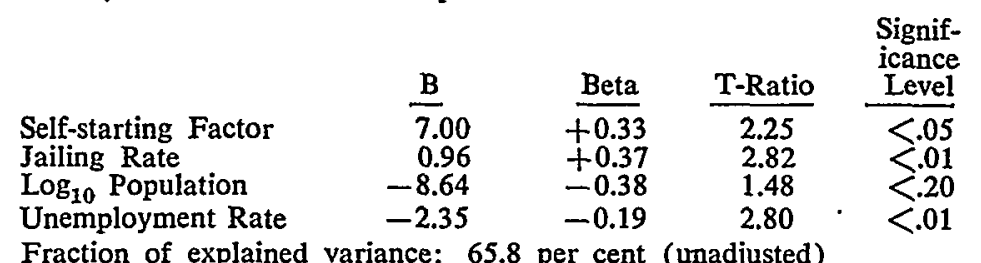

Fraction of explained variance: 65.8 per cent (unadjusted)

59.9 per cent (adjusted)

3. With the "High-Jail/Self-Start Factor":

\begin{tabular}{|c|c|c|c|c|}
\hline & $\mathbf{B}$ & Beta & T-Ratio & $\begin{array}{l}\text { Signif- } \\
\text { icance } \\
\text { Level }\end{array}$ \\
\hline \multicolumn{5}{|l|}{ High-Jail/Self-Start } \\
\hline Factor & 14.8 & +.64 & 6.36 & $<.01$ \\
\hline $\log _{10}$ Population & -10.8 & -.47 & 4.72 & $<.01$ \\
\hline Unemployment Rate & -2.65 & -.22 & 2.20 & $<.05$ \\
\hline \multicolumn{5}{|c|}{$\begin{array}{l}\text { Fraction of explained variance: } 76.5 \text { per cent (unadjusted) } \\
73.6 \text { per cent (adjusted) }\end{array}$} \\
\hline \multicolumn{5}{|c|}{ With the "Jail $x$ Self-Start Factor": } \\
\hline & & & & Signif- \\
\hline & B & Beta & T-Ratio & Level \\
\hline $\begin{array}{l}\text { Jail } \times \text { Self-Start Factor } \\
\log _{10} \text { Population }\end{array}$ & $\begin{array}{r}+1.33 \\
-9.96\end{array}$ & $\begin{array}{l}+.55 \\
-.43\end{array}$ & $\begin{array}{l}4.30 \\
3.50\end{array}$ & $<.01$ \\
\hline Unemployment Rate & -1.94 & -.16 & 1.25 & - \\
\hline \multicolumn{5}{|c|}{$\begin{array}{l}\text { Fraction of explained variance: } 64.4 \text { per cent (unadjusted) } \\
60.1 \text { per cent (adjusted) }\end{array}$} \\
\hline
\end{tabular}

B. Regression on $\log _{10}$ "Mean Payment Rate"

With principal variables in log form:

\begin{tabular}{|c|c|c|c|c|}
\hline & B & Beta & T-Ratio & $\begin{array}{l}\text { Signif- } \\
\text { icance } \\
\text { Level }\end{array}$ \\
\hline $\begin{array}{l}\text { Self-starting Factor } \\
\log _{10} \text { Jail Rate } \\
\log _{10} \text { Population } \\
\log _{10} \text { Unemployment }\end{array}$ & $\begin{array}{r}0.047 \\
0.052 \\
-0.059 \\
-0.240\end{array}$ & $\begin{array}{l}+0.33 \\
+0.31 \\
-0.38 \\
-0.23\end{array}$ & $\begin{array}{l}2.06 \\
2.20 \\
2.69 \\
1.62\end{array}$ & $\begin{array}{l}<.05 \\
<.05 \\
<.01 \\
<.20\end{array}$ \\
\hline
\end{tabular}

Fraction of explained variance: 62.1 per cent (unadjusted)

55.5 per cent (adjusted) 
C. Regression on "Mean Payment Rate" in modified "Logit" form $\log _{10} \frac{\text { Mean Payment Rate }}{1-\text { Mean Payment Rate }}$

With principal measures in log form:

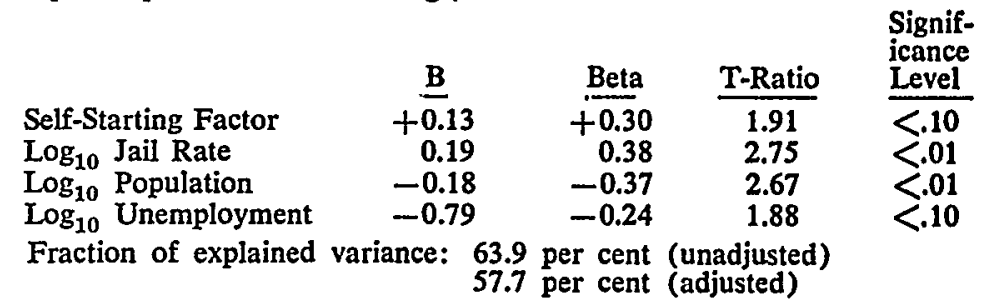

